\title{
Sources and dynamics of sedimentary organic matter in Sundarban mangrove estuary from Indo-Gangetic delta
}

\author{
M. Bala Krishna Prasad ${ }^{1 *}$, Alok Kumar², A.L. Ramanathan² and Dilip Kumar Datta ${ }^{3}$
}

\begin{abstract}
Introduction: Mangrove forests are highly productive ecosystems distributed along the tropical coast line. Nutrient biogeochemistry of mangroves are primarly driven by both allochthonous and autochthonous sources. Characterization of organic matter in coastal ecosystems enables to understand the biogeochemical transformation of organic matter and its influence on ecosystem productivity in response to various changing environmental conditions. Therefore, the elemental and stable carbon and nitrogen levels were employed to understand the organic matter (OM) dynamics in the Sundarban mangrove ecosystem (India-Bangladesh).

Results: Differences in stable isotope values indicate that variable sources influence the OM dynamics in Sundarban sediments. The progressive enrichment in $\delta 13 \mathrm{C}$ levels along the land-coastal continuum indicates that the terrestrial and marine inputs are dominant at the landward and seaward ends, respectively. The CuO oxidationderived lignin phenol monomers describe significant levels of total lignin are preserved in Sundarban mangrove sediments during diagenesis. The phenol monomer ratios are lower than the plant litter explaining that aromatic ring cleavage is the dominant mechanism for the lignin degradation. Furthermore, the Ad/Al ratios were higher than the plant litter explaining the oxidation of propyl side chain of vascular OM influencing the carbon cycling in Sundarban sediments. Largely, the Ad/Al ratios describe the vascular OM degradation is through the oxidation of propyl side chain.

Conclusions: The regional variability in land-use regulates the spatial variability in C, N, OC/TN ratio, $\delta 13 \mathrm{C}$ and $\delta$ $15 \mathrm{~N}$ between the Indian and the Bangladesh Sundarban mangroves and indicates that in the upstream terrestrial organic matter and/or mangrove plant litter contribute significant amount of organic matter, whereas the marine POC influences the organic matter dynamics in downstream. The three end-member mixing model applying terrestrial plant litter, seston, and marine $P O C$ as end-members explains the relative contribution of OM from various sources, and marine inputs were dominant in Sundarban sediments.
\end{abstract}

Keywords: Sundarban mangrove, Organic carbon, Stable isotopes, Lignin phenols, Three end-member mixing model

\section{Introduction}

Being situated in a transboundary position between land and ocean, mangroves generally act as a bioreactor that alters the chemistry of terrestrial organic matter and supplies large amounts of organic matter to the adjacent coastal ocean and influencing the ocean biogeochemistry (Dittmar et al. 2006). A substantial amount of carbon and nutrients is also accumulated in sediments and this has

\footnotetext{
* Correspondence: mbkprasad@gmail.com

${ }^{1} 22616$ Shining Harness Street, Clarksburg, MD 20871, USA

Full list of author information is available at the end of the article
}

becomes an unaccounted portion in the global carbon and nutrient budgeting; therefore, assessment of sedimentary carbon and nutrient pools is highly important to fill the gaps in the global dataset (Kristensen et al. 2008).

Both allochthonous (e.g., riverine loadings) and autochthonous sources (e.g., coastal wetlands and seagrass ecosystems, mangrove litter, benthic vegetation, freshwater, and marine particulate organic matter) supply organic matter to coastal ecosystems (Kristensen et al. 2008; Jennerjahn 2012). Characterization of organic matter in coastal ecosystems enables to understand the biogeochemical transformation of organic matter and its 
influence on ecosystem productivity in response to various changing environmental conditions. The $\mathrm{C} / \mathrm{N}$ ratios have been extensively used as a proxy to identify organic matter sources, and stable $\mathrm{C}\left(\delta^{13} \mathrm{C}\right)$ and $\mathrm{N}\left(\delta^{15} \mathrm{~N}\right)$ isotopes have also been extensively applied to characterize the origin and fate of organic matter in estuarine mangrove ecosystems (Kristensen et al. 2008; Prasad and Ramanathan 2009). The physiological differences in the $\mathrm{CO}_{2}$ fixation during photosynthesis resulted in differences in the $\delta^{13} \mathrm{C}$ levels in C3 and C4 plants, which are used as a proxy to differentiate plant-derived organic matter sources in coastal ecosystems (Lamb et al. 2006). Largely, terrestrial plants contain $\delta^{15} \mathrm{~N}$ levels $\sim 0 \%$ (Thornton and McManus 1994), whereas mangrove plant $\delta^{15} \mathrm{~N}$ levels ranges from $-1.5 \%$ to 3.2\% (Muzuka and Shunula 2006) and anthropogenic sources contain $>8 \%$ (Prasad and Ramanathan 2009), and these can be used in distinguishing nitrogen sources in coastal ecosystems.

The origin and fate of organic matter in the Indian subcontinent mangrove ecosystems are rarely studied in detail. This is a critical issue in understanding the global carbon cycle and to develop the carbon budget for mangrove ecosystems. Especially, the various organic matter sources along the land-coast continuum are largely influenced by both natural and anthropogenic perturbations (Prasad et al. 2013). Hence, it is crucial to understand the biogeochemical cycling of organic matter in mangroves. The Sundarban mangrove ecosystem in the Gangetic delta in India and Bangladesh is very important coastal ecosystem and is also highly vulnerable to climate change (Mitra et al. 2009). It has been estimated that the Indian Sundarban inputs $13.8 \mathrm{~kg} \mathrm{C} \mathrm{ha}^{-1}$ of $\mathrm{CO}_{2}$ to the atmosphere which is largely (60\%) derived from the biological degradation of organic matter (Biswas et al. 2004). This clearly indicates that organic matter in Sundarban is highly labile in nature and may be derived from various sources. It is extremely important to understand the variability in sources and dynamics of organic matter along the land and sea continuum of Sundarban. Therefore, this research study is intended to delineate the origin and fate of organic matter and to apply the three end-member mixing model to estimate the relative contributions of organic matter from various sources in the Sundarban mangrove sediments from both India and Bangladesh. This study is also expected to deliver a better understanding of the ongoing biogeochemical processes in the vertical sediment profiles from the Sundarban mangrove.

\section{Methods}

\section{Study area}

Sundarban is the largest single-block mangrove ecosystem in the world and is distributed in the Gangetic delta with an area of $10,200 \mathrm{~km}^{2}$ of which $60 \%$ is distributed in Bangladesh and the rest $40 \%$ in India (Fig. 1). The climate is humid tropical to sub-tropical and is influenced by the Bay of Bengal. The mean annual maxima and minima temperatures recorded at the Jhingakhalli meteorological station were 34 and $20{ }^{\circ} \mathrm{C}$, respectively. Similarly, the mean annual rainfall varies between 1800 and $1920 \mathrm{~mm}$ and tides are semidiurnal tides $(2-4 \mathrm{~m})$. The dominant plant species in the Bangladesh Sundarban are Heritiera fomes, Excoecaria agallocha, Ceriops decandra, and Sonneratia apetala. In addition to these species, Rhizophora mangle, $R$. mucronata, $R$. apiculata, Bruguiera gymnorrhiza, and Avicennia officinalis are dominant. H. fomes (sundari) is the dominant species in the freshwater-dominant tidal zones, especially in the northeast, and forms $60 \%$ of the commercially useful timber. In addition to the above species, Bruguiera gymnorrhiza, A. marina, R. mucronata, Acanthus ilicifolias, Lumnitzera racemosa, Cynometra ramiflora, Excoecaria agallocha, etc. are also dominant plant species in the Indian Sundarbans (Mandal et al. 2012).

Like other mangrove ecosystems, Sundarban is also highly degraded by anthropogenic activities, like industrial, domestic, and shipping activities (Baneerjee et al. 2012, Banerjee et al. 2012). Sundarban is rich in biodiversity and is a favorable habitat for the Royal Bengal Tigers. However, rapid changes in land use pattern/management, discharges of agriculture and aquaculture effluents, and reduction in freshwater from the upstream due to the construction of dams have seriously affected the biodiversity and biogeochemical processes in Sundarban (Erwin 2009). Furthermore, climate change induced sea level rise could inundate about $1000 \mathrm{~km}^{2}$ of the mangrove area (Bose 2006). This creates a wide range of ecological and socio-economic problems in the region, leading to crisis in the livelihoods of the poor and marginalized people. Mangrove forests which are considered to be the lifeline of this region are declining at an alarming rate due to land use change, sea level rise, soil texture, tidal actions as well as ecological factors arising out of increasing biotic pressure (Gopal and Chauhan 2006).

\section{Sampling and analysis}

The core sediments, 4 core sediments from Bangladesh Sundarban and 3 core sediment samples from Indian Sundarban, were collected (Fig. 1) along the land and coast continuum using a $1.5-\mathrm{m}$-long plexiglass corer (7 cm i.d.) in February 2012. The collected core samples were immediately transported to the field laboratory and sectioned into $1-\mathrm{cm}$ interval. The core sections were packed in a precleaned polythene bags and stored at $4^{\circ}$ $\mathrm{C}$ until analysis. In the laboratory, air dried samples crushed and sieved through a $250 \mu \mathrm{M}$ mesh to remove coarse sand and large plant debris. The crushed 


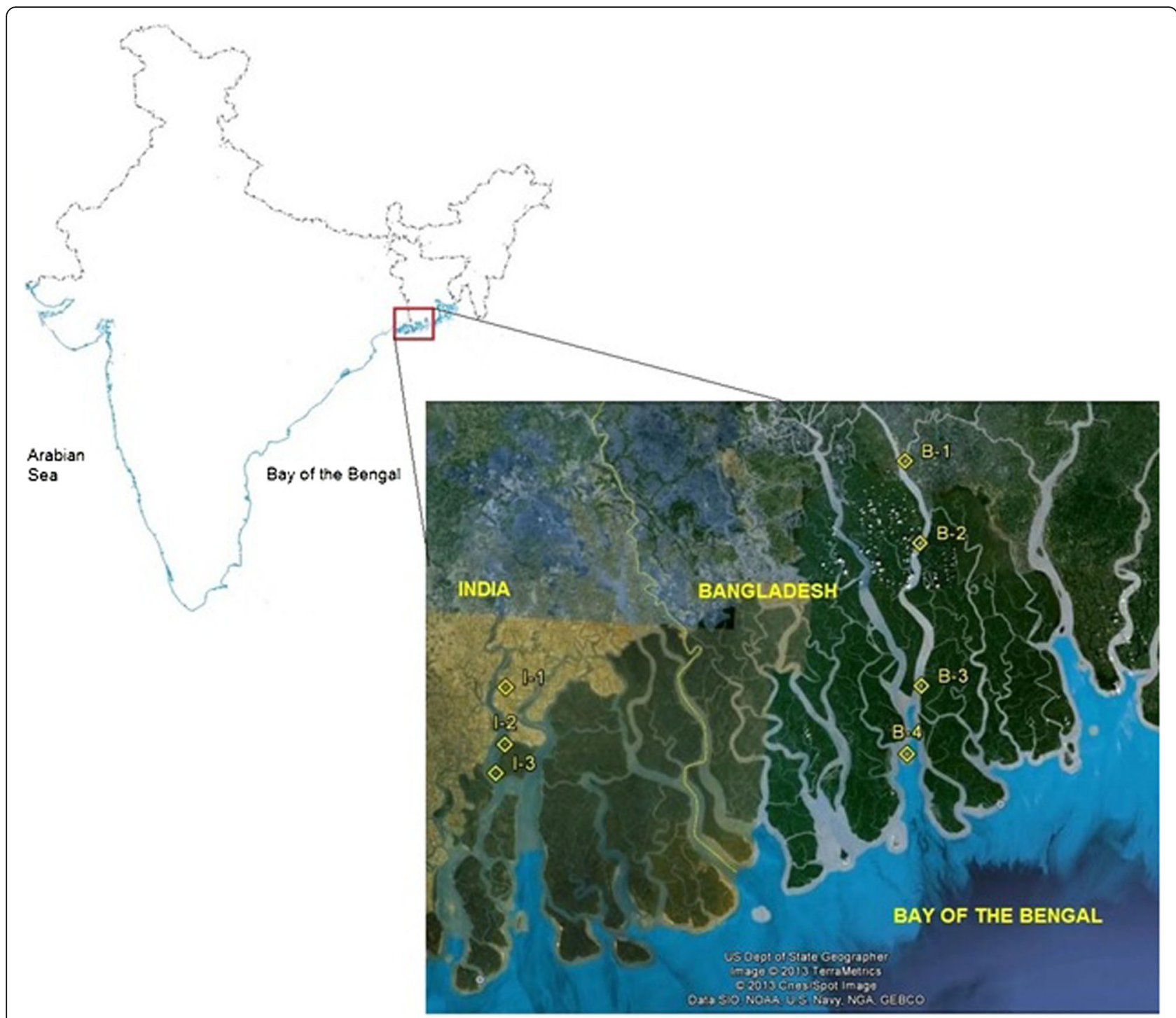

Fig. 1 The map of the Sundarban mangrove from India and Bangladesh with sampling locations

sediment was sieved through the ASTM standard sieves, and only fractions $<32 \mu \mathrm{M}$ were analyzed for organic carbon (OC), total nitrogen (TN), and $\delta^{13} \mathrm{C}$ and $\delta^{15} \mathrm{~N}$ isotopes. Samples were decarbonized using $1 \mathrm{~N} \mathrm{HCl}$, rinsed with distilled water to remove salt components, and then again air dried.

About $50 \mathrm{mg}$ of dried sediment weighed in a tin capsules was analyzed using automated continuous-flow isotope ratio mass spectrometry (Preston and Owens 1983). The samples are combusted in a EuroVector CN elemental analyzer. The combustion gases $\left(\mathrm{N}_{2}\right.$ and $\left.\mathrm{CO}_{2}\right)$ were separated on a GC column, passed through a GVI (GV Instruments) diluter and reference gas box, and finally introduced into the GVI IsoPrime isotope ratio mass spectrometer. Ratios of ${ }^{13} \mathrm{C} /{ }^{12} \mathrm{C}$ and ${ }^{15} \mathrm{~N} /{ }^{14} \mathrm{~N}$ were expressed as the relative per mil (\%o) difference between the samples and international standards (Vienna PDB carbonate and $\mathrm{N}_{2}$ in air, respectively):

$$
\delta X(\%)=\left[\left(\frac{R_{\text {sample }}}{R_{\text {standard }}}\right)-1\right] \times 1000
$$

where $X={ }^{13} \mathrm{C}$ or ${ }^{15} \mathrm{~N}$ and $R={ }^{13} \mathrm{C} /{ }^{12} \mathrm{C}$ or ${ }^{15} \mathrm{~N} /{ }^{14} \mathrm{~N}$. The precision for $\mathrm{C}$ and $\mathrm{N}$ isotope analyses was \pm 0.15 and $\pm 0.05 \%$, respectively. The sample isotope ratios were compared to a secondary gas standard. For ${ }^{13} \mathrm{C}_{\mathrm{V} \text {-PDB }}$, the gas was calibrated against NBS 20 (Solenhofen Limestone). For ${ }^{15} \mathrm{~N}_{\text {air }}$ the gas was calibrated against atmospheric $\mathrm{N}_{2}$ and IAEA standards (N-1, N-2, and N-3). All international standards were obtained from the National Bureau of Standards in Gaithersburg (MD, USA). 
Lignin was analyzed by disrupting its macromolecular structure by alkaline $\mathrm{CuO}$ oxidation (Hedges and Ertel 1982; Lobbes et al. 1999). A suite of phenolic monomers derived by this method was analyzed by a high performance liquid chromatography. The analysis was conducted on a Merck-Hitachi HPLC system with diode array detection using a reverse phase column (Lichrosphere $100 \mathrm{RP} 18,5 \mathrm{~mm}$ particle diameter, $250 \mathrm{~mm}$ length, $4 \mathrm{~mm}$ inner diameter) and a multi-step solvent gradient system for separation. The phenols were identified by their retention times and UV absorption spectra between 230 and $370 \mathrm{~nm}$, recorded continuously by the diode array detection detector, and the extinction at $280 \mathrm{~nm}$ was used for quantification. External standards of the 11 phenols (Fluka, Switzerland; Aldrich, USA; Sigma, USA) were used for calibration. The detection limit for the individual phenols ranged from 15 to 40 pmol $(p=0.05)$. All samples were analyzed in duplicate, including $\mathrm{CuO}$ oxidation, extraction, and quantification. The coefficient of variation $(\mathrm{CV})$ was $15 \%$ on average that agrees well with data reported elsewhere (Lobbes et al. 1999). The CV of the HPLC quantification was $<3 \%$.

\section{Three end-member mixing model}

Generally, in the river-dominated intertidal mangrove ecosystems, OM dynamics are largely regulated by sources from terrestrial plant litter, seston, and marine particulate organic carbon (POC) (Prasad et al. 2010). Using these three end-members, a ternary mixing model can be employed to estimate OM sources and the end-member organic matter source occupies a corner of the triangle (Dittmar et al. 2001). Samples within the triangle defined by end-members A, B, and C; these are terrestrial plant litter, seston, and marine particulate organic carbon (POC), respectively. Samples that fall along any of the lines connecting two end-members are a mixture of only those two organic matter types. Samples that fall outside of the triangle indicate the presence of additional sources or diagenetic modifications of the original signal and cannot be characterized by this model. Using the example described by Dittmar et al. (2001), it is possible to expand the usability of this three end-member mixing model by creating a tolerance interval $(\tau)$ as

$$
\tau=\frac{a^{\prime}}{a} \times 100 \%=\frac{b^{\prime}}{b} \times 100 \%=\frac{c^{\prime}}{c} \times 100 \%
$$

where $\tau$ is the tolerance level (\%) which determines the range of values that still be considered as defined by three end-member mixing model; $a, b$, and c characterizing the strict validity of the model, and $a^{\prime}, b^{\prime}$, and $c^{\prime}$ characterizing the expanded validity of the model. A $10 \%$ tolerance level was applied in this study. Samples fall outside the validity line but within the expanded area (tolerance level) are treated as the same samples that fall on the tie lines and are a mixture of only two sources. Samples that fall outside of the triangle at the vertices but within the expanded triangle are ascribed completely to the sources at the vertex.

\section{Results}

Statistically significant spatial variability $\left(t_{\text {stat }}=1.87, t_{\text {crit }}=\right.$ $2.05, p<0.05)$ in $\mathrm{OC}, \mathrm{TN}, \mathrm{OC} / \mathrm{TN}$ ratio, $\delta^{13} \mathrm{C}$, and $\delta^{15} \mathrm{~N}$ was observed between the Indian Sundarban (IS) and the Bangladesh Sundarban (BS) mangrove sediments (Table 1). High levels of OC were observed in IS (0.76-5.22\%) than in those in BS (0.92-2.41\%; Table 1). Similarly, high TN $(0.043-0.15 \%)$ values were observed in IS, whereas TN ranges between 0.045 and $0.105 \%$ in BS (Table 1). The spatial variations in $\mathrm{OC}$ and $\mathrm{TN}$ are clearly imprinted in the $\mathrm{OC} / \mathrm{TN}$ ratios in both IS and BS. Highly variable $\delta^{13} \mathrm{C}$ signatures $(-26.80$ to $-10.96 \%$ o) were observed in IS sediments, whereas $\delta^{13} \mathrm{C}$ value in BS sediments ranges from -23.54 to $-13.14 \%$. And $\delta^{15} \mathrm{~N}$ values were ranged between $0.09-12.24 \%$ in IS sediments and $0.05-17.54 \%$ in BS sediments (Table 1).

\section{C, N, and stable isotopes}

The vertical variability in $\mathrm{OC}(\%), \mathrm{TN}(\%), \mathrm{OC} / \mathrm{TN}$ ratio, $\delta^{13} \mathrm{C}$, and $\delta^{15} \mathrm{~N}$ of IS sediments is shown in Fig. 2. High levels of OC $(0.97-5.22 \%)$ in IS2 sediment were observed in the middle zone $(20-25 \mathrm{~cm})$, but no vertical

Table 1 Concentrations [range (avg \pm SD)] of OC, TN, OC/TN ratio, $\delta^{13} \mathrm{C}$, and $\delta^{15} \mathrm{~N}$ in the Sundarban sediments

\begin{tabular}{|c|c|c|c|c|c|c|c|}
\hline Variable & IS1 & IS2 & IS3 & $\mathrm{BS} 1$ & BS2 & BS3 & BS4 \\
\hline $\mathrm{OC}(\%)$ & $\begin{array}{l}0.76-1.93 \\
(0.93 \pm 0.15)\end{array}$ & $\begin{array}{l}0.76-5.22 \\
(6.72 \pm 1.14)\end{array}$ & $\begin{array}{l}0.81-1.3 \\
(0.92 \pm 0.1)\end{array}$ & $\begin{array}{l}1.12-2.41 \\
(1.5 \pm 0.26)\end{array}$ & $\begin{array}{l}0.92-1.34 \\
(1.13 \pm 0.09)\end{array}$ & $\begin{array}{l}0.92-1.56 \\
(1.10 \pm 0.12)\end{array}$ & $\begin{array}{l}1.13-1.73 \\
(1.27 \pm 0.12)\end{array}$ \\
\hline TN (\%) & $\begin{array}{l}0.057-0.15 \\
(0.068 \pm 0.012)\end{array}$ & $\begin{array}{l}0.062-0.11 \\
(0.074 \pm 0.009)\end{array}$ & $\begin{array}{l}0.043-0.092 \\
(0.065 \pm 0.011)\end{array}$ & $\begin{array}{l}0.1-0.105 \\
(0.082 \pm 0.01)\end{array}$ & $\begin{array}{l}0.045-0.066 \\
(0.052 \pm 0.004)\end{array}$ & $\begin{array}{l}0.056-0.073 \\
(0.065 \pm 0.004)\end{array}$ & $\begin{array}{l}0.05-0.08 \\
(0.06 \pm 0.006)\end{array}$ \\
\hline $\begin{array}{l}\mathrm{OC} / \mathrm{TN} \\
\text { ratio }\end{array}$ & $\begin{array}{l}11.43-16.19 \\
(13.52 \pm 1.20)\end{array}$ & $\begin{array}{l}10.56-48 \\
(14 \pm 5.98)\end{array}$ & $\begin{array}{l}11.48-19.41 \\
(14 \pm 1.74)\end{array}$ & $\begin{array}{l}15.57-27 \\
(18 \pm 1.99)\end{array}$ & $\begin{array}{l}16.16-25.58 \\
(22 \pm 1.83)\end{array}$ & $\begin{array}{l}14.67-21.48 \\
(17 \pm 1.25)\end{array}$ & $\begin{array}{l}18.58-30.56 \\
(21 \pm 2.31)\end{array}$ \\
\hline $\begin{array}{l}\delta^{13} \mathrm{C} \\
(\% 0)\end{array}$ & $\begin{array}{l}-21.55 \text { to }-14.76 \\
(-18.88 \pm 0.97)\end{array}$ & $\begin{array}{l}-26.8 \text { to }-16.26 \\
(-19.64 \pm 2.38)\end{array}$ & $\begin{array}{l}-21.56 \text { to }-10.96 \\
(-16.41 \pm 2.14)\end{array}$ & $\begin{array}{l}-23.54 \text { to }-16.4 \\
(-19.42 \pm 1.76)\end{array}$ & $\begin{array}{l}-17.44 \text { to }-13.77 \\
(-15.28 \pm 0.88)\end{array}$ & $\begin{array}{l}-18.32 \text { to }-15.1 \\
(-16.73 \pm 0.73)\end{array}$ & $\begin{array}{l}-19.79 \text { to }-13.14 \\
(-15.49 \pm 1.27)\end{array}$ \\
\hline $\begin{array}{l}\delta^{15} \mathrm{~N} \\
(\% 0)\end{array}$ & $\begin{array}{l}0.09-12.24 \\
(3.88 \pm 0.76)\end{array}$ & $\begin{array}{l}3.06-5.16 \\
(4.09 \pm 0.45)\end{array}$ & $\begin{array}{l}3.28-5.6 \\
(4.48 \pm 0.56)\end{array}$ & $\begin{array}{l}0.05-17.55 \\
(0.016 \pm 0.0017)\end{array}$ & $\begin{array}{l}1.61-11.76 \\
(5.02 \pm 1.81)\end{array}$ & $\begin{array}{l}2.35-4.14 \\
(3.31 \pm 0.33)\end{array}$ & $\begin{array}{l}1.61-4.13 \\
(2.99 \pm 0.4)\end{array}$ \\
\hline
\end{tabular}



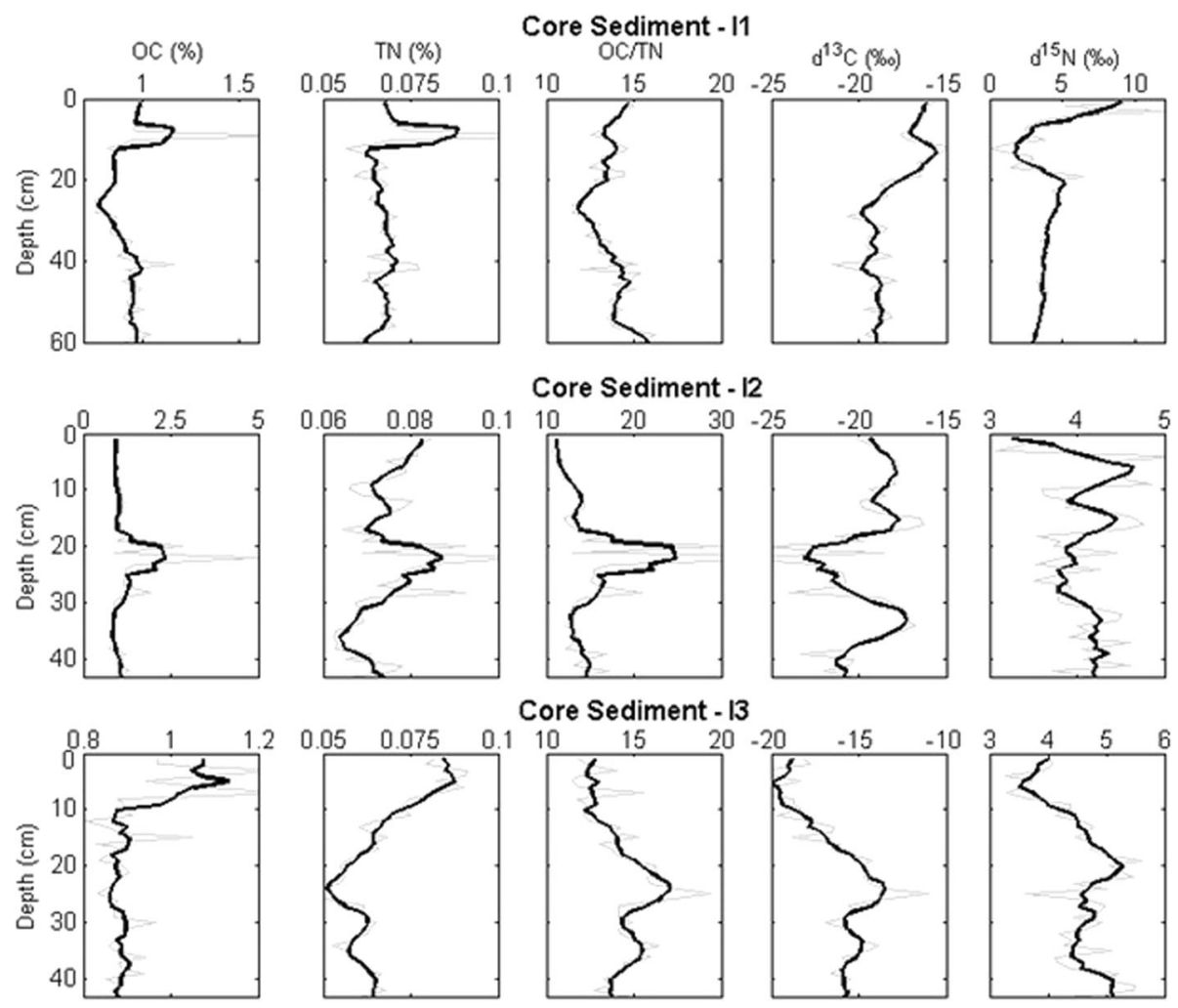

Core Sediment - 13
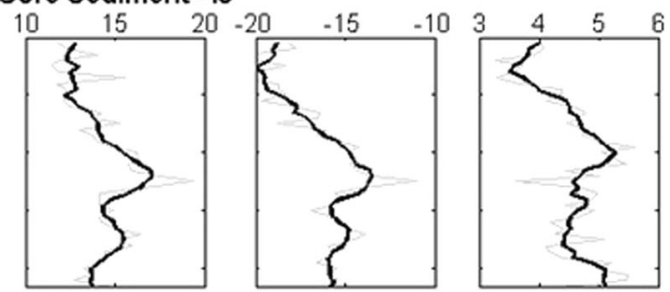

Fig. 2 Vertical variability with the thick layer of $11 \mathrm{~cm}$ moving average levels in $\mathrm{OC}, \mathrm{TN}, \mathrm{OC} / \mathrm{TN}$ ratio, $\delta^{13} \mathrm{C}$, and $\delta^{15} \mathrm{~N}$ from the Indian Sundarban sediments

variability was observed in IS1 and IS3 sediments. TN increased from $0.7-0.15 \%$ to $0.082-0.11 \%$ in the top 10 and $22 \mathrm{~cm}$ of IS1 and IS2 sediments, whereas TN decreased from surface to deep layer in IS3. The OC/TN ratios were also decreased with depth in IS1, whereas the $\mathrm{OC} / \mathrm{TN}$ ratio was increased up to $20 \mathrm{~cm}$ and then decreased with depth in IS3.

In IS1, $\delta^{13} \mathrm{C}$ value decreased from -15.61 to $-17.24 \%$ in the top $10 \mathrm{~cm}$ and then slightly increased to $-14.76 \%$ around $15 \mathrm{~cm}$ and again decreased with depth (Fig. 2). The $\delta^{13} \mathrm{C}$ value in IS2 increased from -20.08 to $-19.77 \%$ in the top $15 \mathrm{~cm}$ and decreased from -24.02 to $-16.07 \%$ between 15 and $30 \mathrm{~cm}$ and again increased to $-16.79 \%$ at $35 \mathrm{~cm}$ depth. However, progressive increase in $\delta^{13} \mathrm{C}$ was observed in IS3 from -18.13 to $-10.96 \%$ in the top $25 \mathrm{~cm}$ and then decreased to $-16.06 \%$ near the bottom of the core (Fig. 2). In IS1, a sharp decrease $(5.21 \%$ at $2 \mathrm{~cm})$ and increase $(12.24 \%$ at $3 \mathrm{~cm})$ in $\delta^{15} \mathrm{~N}$ value were observed in the top $3 \mathrm{~cm}$ and decreased to $0.09 \%$ at $12 \mathrm{~cm}$, but afterwards, increased to $6.47 \%$ at $20 \mathrm{~cm}$ and then decreased. In IS2, $\delta^{15} \mathrm{~N}$ value increased from 3.28 to $4.79 \%$ in the top $16 \mathrm{~cm}$ and then decreased with depth. Similarly, in IS3, $\delta^{15} \mathrm{~N}$ increased from 4.03 to $5.09 \%$ in the top $20 \mathrm{~cm}$ and decreased with depth (Fig. 2).
The vertical variability in OC (\%), TN (\%), OC/TN ratio, $\delta^{13} \mathrm{C}$, and $\delta^{15} \mathrm{~N}$ of $\mathrm{BS}$ sediments is shown in Fig. 3. In BS1 and BS3, OC increased in the top $5 \mathrm{~cm}$ and then decreased with depth. However, OC decreased in the top $5 \mathrm{~cm}$ and increased with depth in BS2. In contrast, OC was remained constant in the top $20 \mathrm{~cm}$ and then increased from 1.22 to $1.43 \%$ in between 20 and $25 \mathrm{~cm}$ depth (Fig. 3). In all samples, except BS2, TN decreased in the top $20 \mathrm{~cm}$ and increased near the bottom of the core. In BS2, the OC/ TN ratio was increased from 17.49 to 23.58 in the top $30 \mathrm{~cm}$ and then decreased, whereas no pattern in the $\mathrm{OC} / \mathrm{TN}$ ratio was observed in BS1 (Fig. 3). In BS3, the OC/TN ratio decreased from 18.08 to 15.32 and remained constant. However, no pattern in the OC/TN ratio was observed in the top $25 \mathrm{~cm}$ and then increased from 20.71 to 29.49 in between 25 and $35 \mathrm{~cm}$ in BS4 (Fig. 3).

In $\mathrm{BS} 1$ and $\mathrm{BS} 2, \delta^{13} \mathrm{C}$ values increased in the top $10 \mathrm{~cm}$ and decreased with depth (Fig. 3). In BS3, $\delta^{13} \mathrm{C}$ values decreased from -16.01 to -17.84 in the top $30 \mathrm{~cm}$ and then increased. But, no vertical pattern in $\delta^{13} \mathrm{C}$ was observed in BS4 up to $25 \mathrm{~cm}$ depth and then increased with depth (Fig. 3). A clear spatial variability in $\delta^{15} \mathrm{~N}$ was observed across the ecosystem. In BS1, 

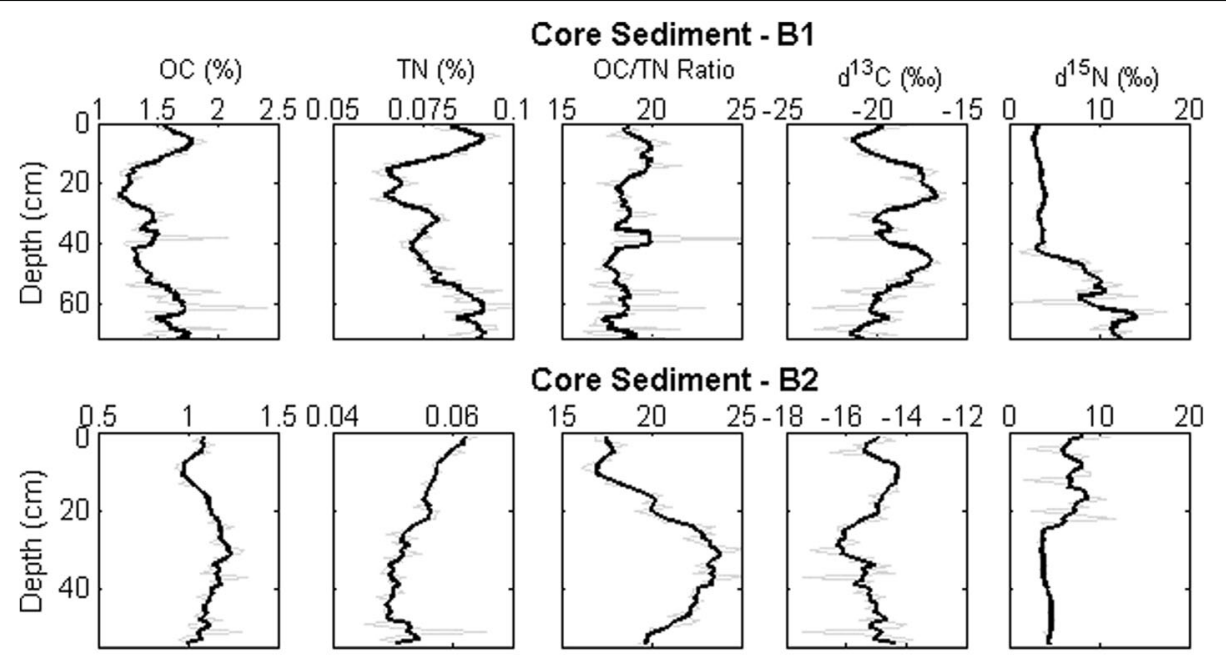

Core Sediment - B3

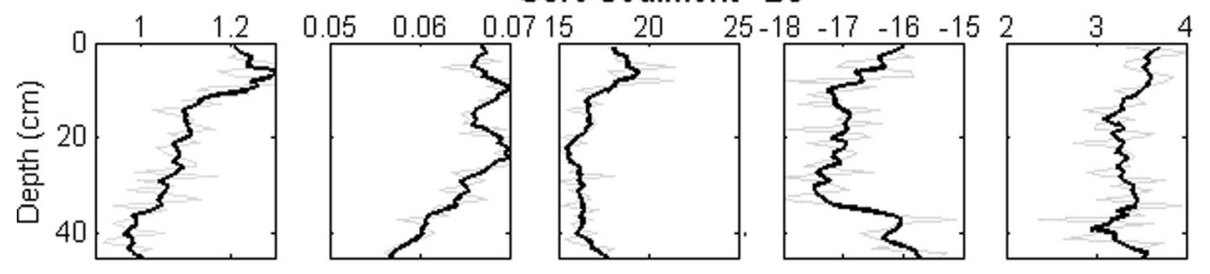

Core Sediment - B4

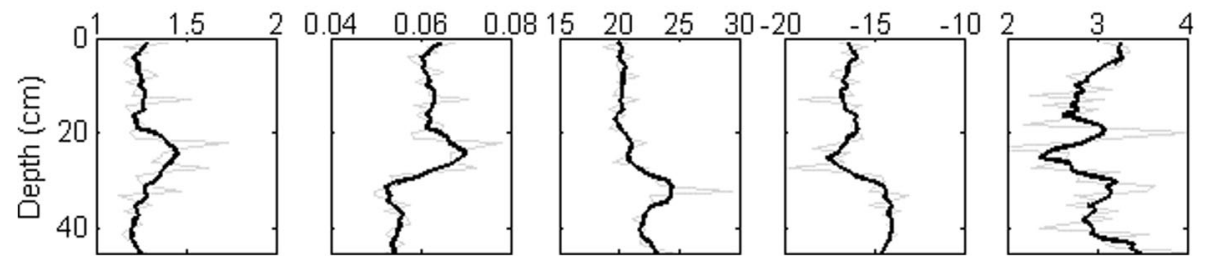

Fig. 3 Vertical variability with the thick layer of $11 \mathrm{~cm}$ moving average levels in $\mathrm{OC}, \mathrm{TN}, \mathrm{OC} / \mathrm{TN}$ ratio, $\delta^{13} \mathrm{C}$, and $\delta^{15} \mathrm{~N}$ from the Bangladesh Sundarban sediments

$\delta^{15} \mathrm{~N}$ was relatively constant up to $40 \mathrm{~cm}$ and then increased to $19 \%$ near the bottom of the core. In BS2, $\delta^{15} \mathrm{~N}$ decreased from 11.21 to $3.5 \%$ in the top $23 \mathrm{~cm}$ and remained constant. In BS3, $\delta^{15} \mathrm{~N}$ values decreased in the top $20 \mathrm{~cm}$ and slightly increased near the bottom of the core. Similarly, $\delta^{15} \mathrm{~N}$ values in BS4 decreased from 3.71 to $2.65 \%$ in the top $22 \mathrm{~cm}$ and then decreased with depth (Fig. 3).

\section{Lignin phenols}

The organic carbon-normalized yields of phenols released by the $\mathrm{CuO}$ oxidation from the Indian and the Bangladesh Sundarban mangrove sediments are given in Table 2. The plant species $H$. fomes, $R$. apiculata, and $A$. marina contain $9.97,10.77$, and $16.34 \%$, respectively, of total lignin $\left(X_{\text {lignin }}\right)$. There are clear spatial differences in the distribution of $X_{\text {lignin }}$ between IS and BS sediments; IS sediments yielded high level of $X_{\text {lignin }}$ about $6.43 \%$ o (5.34-6.39\%o) than the BS sediments, 4.66\%o (2.78$6.78 \%$; Figs. 4 and 5). In IS1, $X_{\text {lignin }}$ levels decreased from 6.34 to $5.34 \%$ in the top $15 \mathrm{~cm}$ and then increased to $6.56 \%$ at $15-40 \mathrm{~cm}$ (Fig. 7). The $X_{\text {lignin }}$ levels increased from 6.55 to $7.45 \%$ in the top $25 \mathrm{~cm}$ and then decreased with depth in IS2. In IS3, $X_{\text {lignin }}$ levels increased from 6.39 to $6.19 \%$ in the top $20 \mathrm{~cm}$ and increased to $6.53 \%$, and then decreased with depth (Fig. 4). In the Bangladesh samples, no trend in $X_{\text {lignin }}$ was observed in the top $25 \mathrm{~cm}$ and then increased to $6.78 \%$ at $40 \mathrm{~cm}$ (Fig. 5). The $X_{\text {lignin }}$ increased in the top $15 \mathrm{~cm}$ in both BS2 (4.67-5.62\%o) and BS3 (2.87-4.32\%o). In BS4, $X_{\text {lignin }}$ increased from 5.33 to $6.34 \%$ in the top $28 \mathrm{~cm}$ and then decreased with depth (Fig. 5).

The p-coumaric acid (CAD) is the principal lignin monomer in angiosperm leaves and yielded in very low levels from all sediment samples. The ratio of cinnamyl phenol $(\mathrm{C})$ to vanillyl phenols $(\mathrm{V})$ was ranged from 0.51 to 0.62 and from 0.79 to 1.25 in IS and BS sediments, respectively (Table 2). Similarly, the ratio of syringyl phenol (S) to vanillyl phenol (V) was ranged from 0.62 to 0.72 in IS sediments and $0.62-0.82$ in BS sediments. The 
Table 2 Concentrations [range (avg \pm SD)] of lignin phenols in the Sundarban Sediments

\begin{tabular}{|c|c|c|c|c|c|c|c|}
\hline Variable & IS1 & 152 & IS3 & BS1 & BS2 & BS3 & BS4 \\
\hline p-Hydroxyl Phenols (P) & $\begin{array}{l}94-115 \\
(105 \pm 5.94)\end{array}$ & $\begin{array}{l}99-117 \\
(110 \pm 6)\end{array}$ & $\begin{array}{l}100-114 \\
(107 \pm 3.96)\end{array}$ & $\begin{array}{l}44-75 \\
(60 \pm 6.48)\end{array}$ & $\begin{array}{l}39-53 \\
(45 \pm 4.39)\end{array}$ & $\begin{array}{l}64-73 \\
(68 \pm 3.03)\end{array}$ & $\begin{array}{l}73-85 \\
(78 \pm 4.19)\end{array}$ \\
\hline Vanillyl Phenols (V) & $\begin{array}{l}64-75 \\
(69 \pm 3.45)\end{array}$ & $\begin{array}{l}65-77 \\
(72 \pm 2.83)\end{array}$ & $\begin{array}{l}75-87 \\
(82 \pm 3.59)\end{array}$ & $\begin{array}{l}28-41 \\
(34 \pm 3.15)\end{array}$ & $\begin{array}{l}21-27 \\
(24 \pm 2.03)\end{array}$ & $\begin{array}{l}39-47 \\
(44 \pm 2.34)\end{array}$ & $\begin{array}{l}50-61 \\
(55 \pm 3.45)\end{array}$ \\
\hline Syringyl Phenols (S) & $\begin{array}{l}39-47 \\
(43 \pm 2.03)\end{array}$ & $\begin{array}{l}45-52 \\
(48 \pm 2.06)\end{array}$ & $\begin{array}{l}56-63 \\
(59 \pm 2.46)\end{array}$ & $\begin{array}{l}21-33 \\
(27 \pm 2.99)\end{array}$ & $\begin{array}{l}14-19 \\
(17 \pm 1.29)\end{array}$ & $\begin{array}{l}23-30 \\
(27 \pm 2.01)\end{array}$ & $\begin{array}{l}32-47 \\
(38 \pm 3.95)\end{array}$ \\
\hline Cinnamyl Phenols (C) & $\begin{array}{l}18-24 \\
(22 \pm 1.92)\end{array}$ & $\begin{array}{l}22-27 \\
(24 \pm 1.6)\end{array}$ & $\begin{array}{l}24-33 \\
(29 \pm 2.61)\end{array}$ & $\begin{array}{l}8-16 \\
(13 \pm 2.28)\end{array}$ & $\begin{array}{l}7.3-14.3 \\
(10.52 \pm 2.02)\end{array}$ & $\begin{array}{l}10-17 \\
(14 \pm 2.28)\end{array}$ & $\begin{array}{l}10-21 \\
(16 \pm 3.01)\end{array}$ \\
\hline $\mathrm{PON} / \mathrm{P}$ & $\begin{array}{l}0.19-0.3 \\
(0.24 \pm 0.03)\end{array}$ & $\begin{array}{l}0.18-0.24 \\
(0.21 \pm 0.02)\end{array}$ & $\begin{array}{l}0.2-0.23 \\
(0.21 \pm 0.008)\end{array}$ & $\begin{array}{l}0.11-0.29 \\
(0.2 \pm 0.04)\end{array}$ & $\begin{array}{l}0.17-0.26 \\
(0.23 \pm 0.03)\end{array}$ & $\begin{array}{l}0.16-0.23 \\
(0.19 \pm 0.02)\end{array}$ & $\begin{array}{l}0.2-0.27 \\
(0.24 \pm 0.02)\end{array}$ \\
\hline$P /(V+S)$ & $\begin{array}{l}0.82-0.99 \\
(0.94 \pm 0.051)\end{array}$ & $\begin{array}{l}0.82-0.96 \\
(0.91 \pm 0.042)\end{array}$ & $\begin{array}{l}0.72-0.85 \\
(0.77 \pm 0.041)\end{array}$ & $\begin{array}{l}0.73-1.29 \\
(0.95 \pm 0.15)\end{array}$ & $\begin{array}{l}0.96-1.31 \\
(1.1 \pm 0.12)\end{array}$ & $\begin{array}{l}0.91-1.02 \\
(0.96 \pm 0.072)\end{array}$ & $\begin{array}{l}0.75-0.9 \\
(0.83 \pm 0.053\end{array}$ \\
\hline SN & $\begin{array}{l}0.55-0.67 \\
(0.62 \pm 0.034)\end{array}$ & $\begin{array}{l}0.59-0.71 \\
(0.21 \pm 0.016)\end{array}$ & $\begin{array}{l}0.65-0.76 \\
(0.72 \pm 0.04)\end{array}$ & $\begin{array}{l}0.67-1.04 \\
(0.82 \pm 0.1)\end{array}$ & $\begin{array}{l}0.53-0.82 \\
(0.69 \pm 0.07)\end{array}$ & $\begin{array}{l}0.5-0.68 \\
(0.62 \pm 0.051)\end{array}$ & $\begin{array}{l}0.62-0.78 \\
(0.69 \pm 0.041)\end{array}$ \\
\hline$C N$ & $\begin{array}{l}0.25-0.38 \\
(0.32 \pm 0.035)\end{array}$ & $\begin{array}{l}0.28-0.39 \\
(0.34 \pm 0.029)\end{array}$ & $\begin{array}{l}0.29-0.4 \\
(0.35 \pm 0.031)\end{array}$ & $\begin{array}{l}0.25-0.5 \\
(0.38 \pm 0.072)\end{array}$ & $\begin{array}{l}0.27-0.54 \\
(0.43 \pm 0.08)\end{array}$ & $\begin{array}{l}0.24-0.4 \\
(0.31 \pm 0.055)\end{array}$ & $\begin{array}{l}0.18-0.36 \\
(0.29 \pm 0.044\end{array}$ \\
\hline$(\mathrm{Ad} / \mathrm{Al})_{\mathrm{P}}$ & $\begin{array}{l}0.72-1.35 \\
(0.98 \pm 0.18)\end{array}$ & $\begin{array}{l}1.27-1.57 \\
(1.42 \pm 0.085)\end{array}$ & $\begin{array}{l}0.93-1.48 \\
(1.20 \pm 0.15)\end{array}$ & $\begin{array}{l}1.29-3.83 \\
(2.41 \pm 0.69)\end{array}$ & $\begin{array}{l}1.37-2.75 \\
(1.88 \pm 0.34)\end{array}$ & $\begin{array}{l}1.23-1.7 \\
(1.46 \pm 0.13)\end{array}$ & $\begin{array}{l}1.23-1.68 \\
(1.38 \pm 0.11)\end{array}$ \\
\hline$(\mathrm{Ad} / \mathrm{Al})_{V}$ & $\begin{array}{l}0.69-1.28 \\
(1.05 \pm 0.19)\end{array}$ & $\begin{array}{l}1.08-1.47 \\
(1.26 \pm 0.13)\end{array}$ & $\begin{array}{l}0.81-1.09 \\
(0.95 \pm 0.1)\end{array}$ & $\begin{array}{l}0.53-1.36 \\
(0.9 \pm 0.22)\end{array}$ & $\begin{array}{l}0.66-1.34 \\
(0.95 \pm 0.23)\end{array}$ & $\begin{array}{l}0.93-1.58 \\
(1.19 \pm 0.19)\end{array}$ & $\begin{array}{l}1.17-1.73 \\
(1.38 \pm 0.19)\end{array}$ \\
\hline$(\mathrm{Ad} / \mathrm{Al})_{\mathrm{S}}$ & $\begin{array}{l}0.42-0.66 \\
(0.53 \pm 0.07)\end{array}$ & $\begin{array}{l}0.41-0.53 \\
(0.48 \pm 0.039)\end{array}$ & $\begin{array}{l}0.59-0.75 \\
(0.67 \pm 0.04)\end{array}$ & $\begin{array}{l}0.38-0.83 \\
(0.56 \pm 0.12)\end{array}$ & $\begin{array}{l}0.49-1.61 \\
(0.99 \pm 0.34)\end{array}$ & $\begin{array}{l}0.52-0.82 \\
(0.67 \pm 0.073)\end{array}$ & $\begin{array}{l}0.56-0.81 \\
(0.65 \pm 0.071)\end{array}$ \\
\hline$X_{\text {lignin }}(\%)$ & $\begin{array}{l}5.34-6.56 \\
(5.89 \pm 0.35)\end{array}$ & $\begin{array}{l}6.39-7.66 \\
(6.82 \pm 0.38)\end{array}$ & $\begin{array}{l}6.19-7.12 \\
(6.59 \pm 0.3)\end{array}$ & $\begin{array}{l}2.78-6.78 \\
(4.32 \pm 1.29)\end{array}$ & $\begin{array}{l}2.87-4.67 \\
(3.72 \pm 0.52)\end{array}$ & $\begin{array}{l}4.52-5.62 \\
(4.94 \pm 0.33)\end{array}$ & $\begin{array}{l}5.06-6.34 \\
(5.68 \pm 0.41)\end{array}$ \\
\hline
\end{tabular}

Units: $\mathrm{P}, \mathrm{V}, \mathrm{S}$, and $\mathrm{C}$ are in micromoles Phenol $\mathrm{OC} / \mathrm{mg} \mathrm{C}$

$P$ p-Hydroxy benzaldehyde (PAL) + p-hydroxyacetophenone (PON) + p-hydroxybenzoic acid (PAD), $V$ Vanillin $(\mathrm{VAL})+$ acetovanillone $(\mathrm{VON})+$ vanillic acid $(\mathrm{VAD})$,

$S$ Syringaldehyde (SAL) + acetosyringone (SON) + syringic acid (SAD), C p-Coumaric acid (CAD) + ferulic acid (FAD)

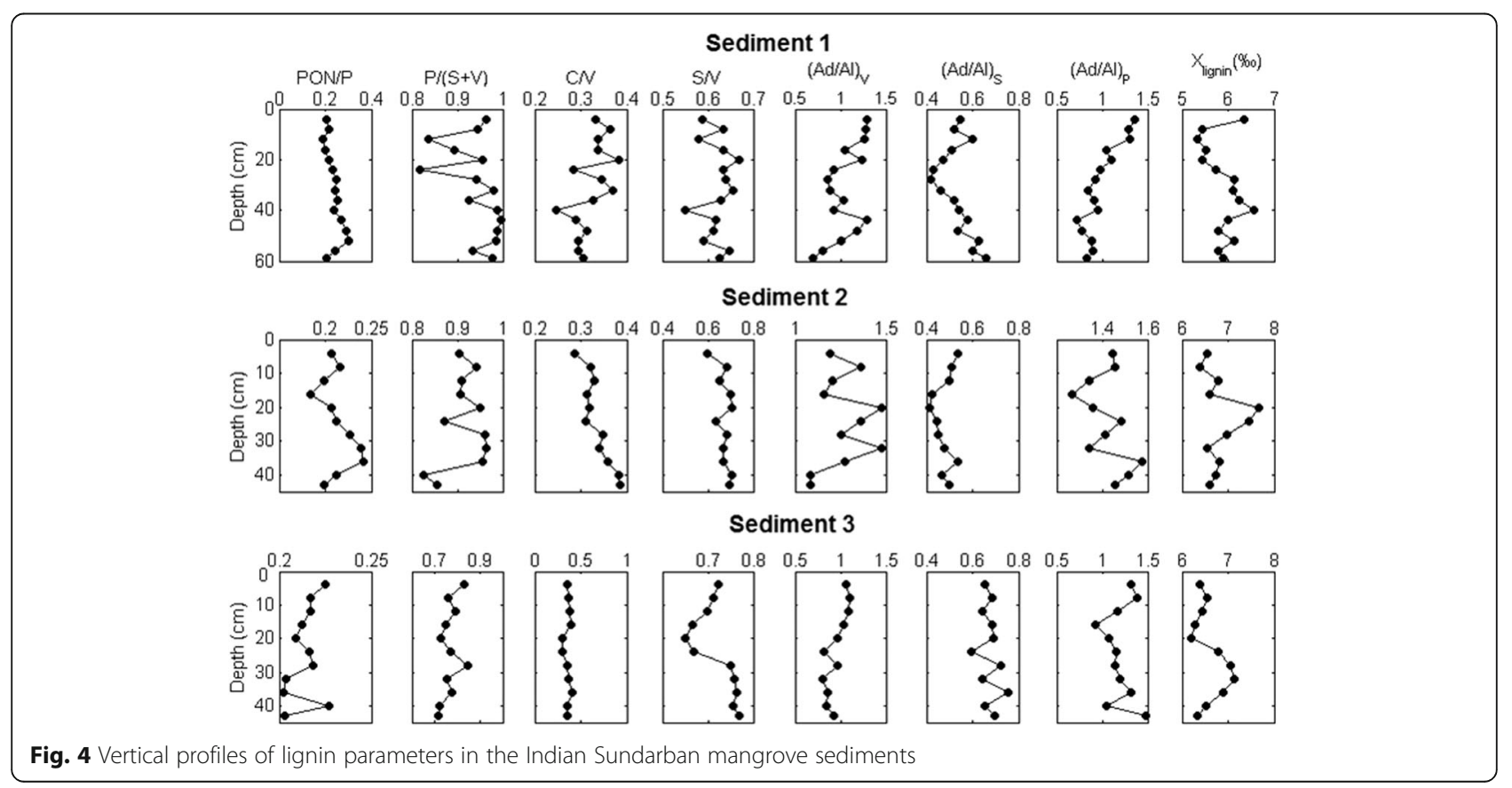






Fig. 5 Vertical profiles of lignin parameters in the Bangladesh Sundarban mangrove sediments

$\mathrm{PON} / \mathrm{P}$ ratio increased and decreased from surface to $35 \mathrm{~cm}$ in IS2 and IS3 sediments, respectively. However, in IS1, the PON/P values were slightly increased at $55 \mathrm{~cm}$ and then decreased with depth. In the Bangladesh samples, the PON/P ratio decreased with depth in BS1, $\mathrm{BS} 2$, and BS3 and increased in BS4. Irregular vertical pattern in the $\mathrm{P} /(\mathrm{S}+\mathrm{V})$ ratio was observed in IS1 and IS2, whereas in IS3, decreased from 0.83 to 0.72 . In BS2, the $\mathrm{P} /(\mathrm{S}+\mathrm{V})$ ratio increased from 1.02 to 1.31 in the top $20 \mathrm{~cm}$ and then decreased to 1.24 at depth. The $\mathrm{P} /(\mathrm{S}+$ $\mathrm{V})$ ratio decreased from 0.89 to 0.75 in $\mathrm{BS} 4$. In all the Indian samples, the $(\mathrm{Ad} / \mathrm{Al})_{\mathrm{V}}$ ratio decreased with depth (Fig. 4). Similarly, the $(\mathrm{Ad} / \mathrm{Al})_{\mathrm{P}}$ ratio also decreased near the bottom of the core in IS1 and IS3 samples. In the Bangladesh samples, the $(\mathrm{Ad} / \mathrm{Al})_{\mathrm{V}}$ ratio decreased down with the core in BS1 and BS2 and increased in BS3. In $\mathrm{BS} 4$, the $(\mathrm{Ad} / \mathrm{Al})_{\mathrm{V}}$ ratio increased from 1.23 to 1.73 in the top $32 \mathrm{~cm}$ and then decreased to 1.16 near the bottom of the core (Fig. 5). Highly variable depth pattern in the $(\mathrm{Ad} / \mathrm{Al})_{\mathrm{V}}$ ratio was observed in all the Bangladesh samples. The $(\mathrm{Ad} / \mathrm{Al})_{\mathrm{S}}$ ratio decreased from surface to the mid zone $(\sim 25 \mathrm{~cm})$ in IS1 and IS2 and highly variable pattern was observed in IS3 (Fig. 4), whereas in the Bangladesh samples, the $(\mathrm{Ad} / \mathrm{Al})_{S}$ ratio largely decreased down with depth of the core (Fig. 5).

\section{Discussion}

\section{Stable isotope ratios}

The stable isotopes evidently characterize the various sources of organic matter in freshwater and coastal ecosystems. The $\delta^{13} \mathrm{C}$ levels in the Sundarban mangrove are comparatively within the global range of mangroves and other coastal ecosystems (Table 3). The results indicate that sedimentary organic matter is predominantly influenced by terrestrial plant inputs, particularly C3 plants in IS and C4 plants in BS (Fig. 6; Lamb et al. 2006). The gradual transformational changes in organic matter sources from the $\mathrm{C} 3$ plants result in the longitudinal decline in $\delta^{13} \mathrm{C}$ levels observed from IS1 to IS3 (Fig. 2). In the upstream station (IS1), the surface $\delta^{13} \mathrm{C}$ value $(-15.6 \%$ o) is close to the C4 plant organic matter ( -17 to $-9 \%$; Deines 1980). We observed that paddy (C4 plant) is being cultivated around the IS1 sampling point, and it might have contributed huge loadings of enriched ${ }^{13} \mathrm{C}$ organic matter in this region. However, the top layer $(\sim 5 \mathrm{~cm})$ of BS sediments of $\delta^{13} \mathrm{C}$ levels (BS1 -18.28\%; BS2 $-14.74 \%$; BS3 -16.08\%; BS4 -16.95\%o) are close to the marine particulate matter, -28 to $-16 \%$ (Fig. 3; Bouillon et al. 2003). The progressive enrichment of $\delta^{13} \mathrm{C}$ in BS and depletion in IS sediments may be controlled either by plant mediated physiological variability in organic matter production or total mixing with enriched organic matter or considerable change in isotope composition due to diagenetic processes in the highly redox mangrove sediments. Various studies also demonstrate that decomposition of plant litter results in enrichment of ${ }^{13} \mathrm{C}$ and ${ }^{14} \mathrm{~N}$ in mangrove and other coastal sediments (Rundegren et al. 2003). In Sundarban, plant litter and particulate and suspended matter are mainly derived from terrigenous matter, phytoplankton, and marine particulates, which are generally considered as dominant organic matter end-members in coastal ecosystems (Gonneea et al. 2004; Prasad and Ramanathan 2009). 
Table 3 Concentrations of OC, TN, and OC/TN ratio, $\delta^{13} \mathrm{C}$, and $\delta^{15} \mathrm{~N}$ from various estuarine and mangrove ecosystems

\begin{tabular}{|c|c|c|c|c|c|c|}
\hline Ecosystem & OC (\%) & TN (\%) & OC/TN ratio & $\delta^{13} \mathrm{C}(\%)$ & $\delta^{15} \mathrm{~N}(\%)$ & Ref. \\
\hline Sundarban, India & $0.76-5.22$ & $0.043-0.15$ & $10.56-47.8$ & -26.80 to -10.96 & $0.09-12.44$ & Present study \\
\hline Sundarban, Bangladesh & $0.92-2.41$ & $0.045-0.105$ & $14.68-29.49$ & -23.54 to -13.14 & $0.05-17.55$ & Present study \\
\hline Pichavaram, India & - & - & $12.99-14.22$ & -15.43 to -22.36 & $5.64-8.12$ & $\begin{array}{l}\text { Prasad and } \\
\text { Ramanathan } 2009\end{array}$ \\
\hline Pichavaram, India & $0.06-1.97$ & $0.01-0.13$ & $5.25-27.3$ & -27.5 to -18.9 & $0.69-6.2$ & Ranjan et al. 2011 \\
\hline Celestun, Mexico & 5.88 & 0.43 & 57.9 & -28.79 & 6.80 & Gonneea et al. 2004 \\
\hline Chelem, Mexico & 1.67 & 0.05 & 53.8 & -26.55 & 7.89 & Gonneea et al. 2004 \\
\hline Terminos, Mexico & 3.33 & 0.33 & 53.4 & -28.93 & 4.31 & Gonneea et al. 2004 \\
\hline Ba Let, Vietnam & - & - & - & -24.81 to -23.43 & - & Tue et al. 2011 \\
\hline Khung Krabaen Bay, Thailand & 11.8 & 0.52 & 26.69 & -27.36 & - & Thimdee et al. 2003 \\
\hline Twin Bay, Belize & $29.4-36.2$ & $1-3$ & $13.9-39.5$ & -24.6 to -20.2 & $-0.4-1.9$ & Wooller et al. 2003 \\
\hline Pearl River Estuary, China & $0.67-4.41$ & $0.06-0.18$ & $8.4-22.4$ & -26.1 to -22.3 & - & He et al. 2010 \\
\hline
\end{tabular}

The vertical variability in $\mathrm{OC}, \mathrm{TN}, \mathrm{OC} / \mathrm{TN}$ ratio, $\delta^{13} \mathrm{C}$, and $\delta^{15} \mathrm{~N}$ shows a complex suite of reactions influencing the biogeochemical cycling of $\mathrm{C}$ and $\mathrm{N}$ in the Sundarban mangrove (Figs. 2 and 3). In addition, rapid changes in land use coupled with climate change exacerbated the carbon and nutrient inputs and this has buried in the deeper sediments and influencing the Sundarban biogeochemistry. An increase in $\delta^{13} \mathrm{C}$ in the top $10-20 \mathrm{~cm}$ depth in BS1, BS2, IS2, and IS3 may be because of an increase in marine input and then show variable pattern near to the bottom of the core. But, the highly variable vertical profile in the $\mathrm{OC} / \mathrm{TN}$ ratios clearly suggests that anthropogenic $\mathrm{N}$ loadings altering the OC/TN stoichiometry (Prasad and Ramanathan 2009). In addition, an increase in the OC/TN ratio in the middle of IS2 and IS3 sediments probably due to high amount of OC is being supplied from the microbial degradation of vegetation (Dittmar and Lara 2001). An increase in $\delta^{13} \mathrm{C}$ and a decrease in OC in BS1 $(40-45 \mathrm{~cm}), \mathrm{BS} 3$ (below $35 \mathrm{~cm}$ ), BS4 (below $30 \mathrm{~cm})$, IS2 $(25-35 \mathrm{~cm})$, and IS3 $(0-25 \mathrm{~cm})$ may be due to large variability in chemistry and increased susceptibility of marine organic matter than the terrestrial/plant organic matter (Hedges et al. 1997). In addition, anaerobic microbial degradation of organic matter in the deep reducing sediments exhibits a small increase in the OC/TN ratio with depth as observed in BS4 (Sweeney and Kaplan 1980; Jennerjahn 2012).

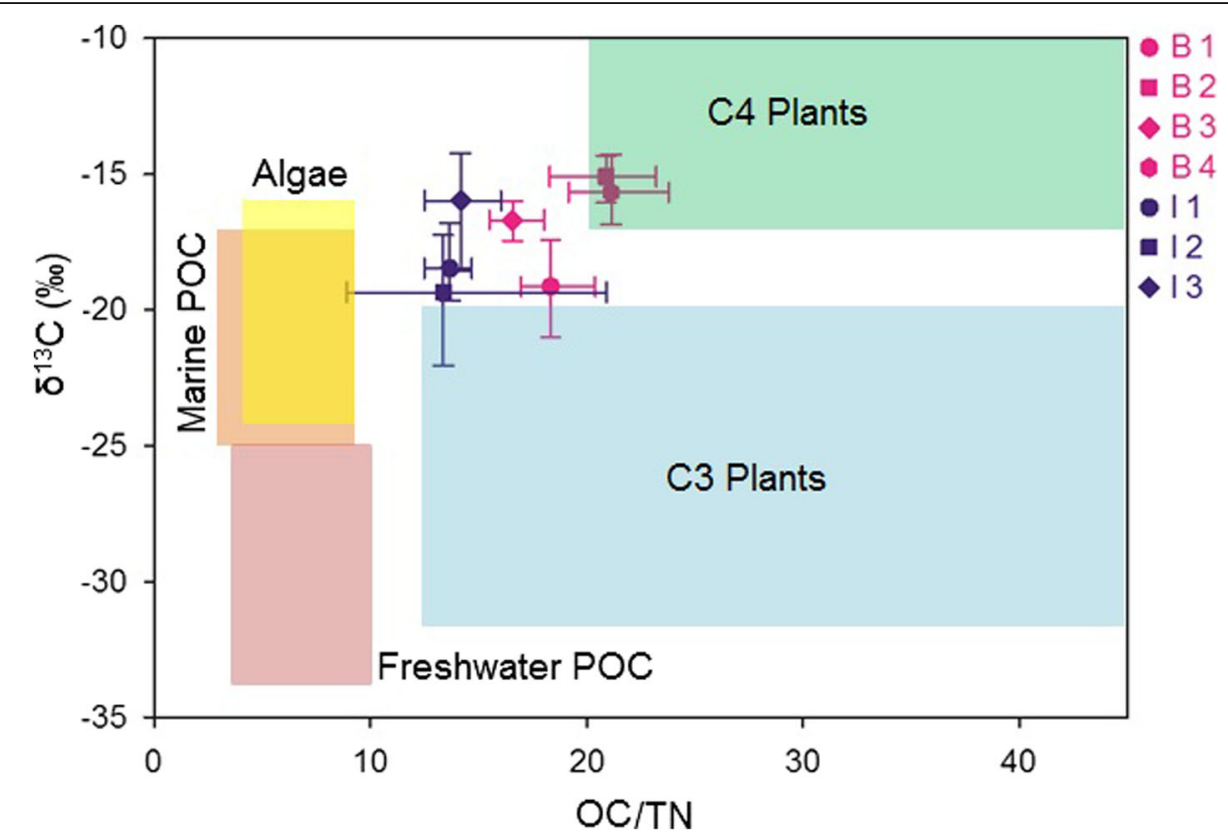

Fig. 6 Representative $\delta^{13} \mathrm{C}$ and OC/TN ranges for organic matter inputs to coastal ecosystems and the Indian and Bangladesh Sundarban mangrove ecosystems (modified after Lamb et al.) 
A decrease in $\delta^{13} \mathrm{C}$ and an increase in the OC/TN ratio in IS2 $(15-22 \mathrm{~cm})$ and BS2 $(10-30 \mathrm{~cm})$ indicate that the terrestrial organic matter inputs are dominant than the marine inputs (Ranjan et al. 2011) and the deposited terrestrial inputs are predominantly refractory in nature. The deep sections of core samples and organic matter quality is largely influenced by terrestrial inputs derived from the Hooghly River (India) and the Rupsa River (Bangladesh), and slight variations may also be linked with microbial mineralization of organic matter in the deep sections of sediment (Andrews et al. 1998).

The nitrogen biogeochemistry is largely influenced by anthropogenic sources in coastal and marine ecosystems (Wigand et al. 2007; Prasad and Ramanathan 2008). Variations in $\delta^{15} \mathrm{~N}$ levels with depth principally depend upon microbial immobilization of anthropogenic nitrogen to fine-grained redox sediments (Groffman and Bohlen 1999). However, the vertical variability in $\delta^{15} \mathrm{~N}$ depends upon many factors like bioavailability of $\mathrm{N}, \mathrm{N}_{2}$ fixation, $\delta^{15} \mathrm{~N}$ levels of allochthonous $\mathrm{N}$, and $\mathrm{N}$ fractionation (Meyers and Arnaboldi 2008). Relatively high $\delta^{15} \mathrm{~N}$ levels observed in IS sediments are due to the ${ }^{15} \mathrm{~N}$ enriched anthropogenic nitrogen pollution altered the nitrogen cycle (Wigand et al. 2007). Singh and Ramesh (2011) reported that $\sim 0.38 \mathrm{Tg} \mathrm{yr}^{-1}$ of terrestrial $\mathrm{N}$ is being supplied through various river systems, including the Hooghly River, to the coastal Bay of Bengal. Similar to the Pichavaram mangrove sediments (Ranjan et al. 2011), an increase in $\delta^{15} \mathrm{~N}$ levels with depth in IS2, IS3, and BS1 sediments indicates that accumulation of ${ }^{15} \mathrm{~N}$ compounds which are derived from anthropogenic activities such as agricultural and aquaculture effluents, domestic sewage, and industrial effluents (Prasad and Ramanathan 2008, 2009). In IS1, BS2, BS3, and BS4 sediments, a decrease in $\delta^{15} \mathrm{~N}$ levels may be attributed to the atmospheric $\mathrm{N}$ deposition and utilization of inorganic nitrogen depleted in $\delta^{15} \mathrm{~N}$ (Ranjan et al. 2011).

Largely, $\delta^{13} \mathrm{C}$ can be used as a proxy to delineate the sources of organic matter in coastal and marine ecosystems. In addition, $\delta^{15} \mathrm{~N}$ and $\mathrm{OC} / \mathrm{TN}$ ratio can also be used in the organic matter characterization, but these two parameters are highly vulnerable to sedimentary diagenesis (Prahl et al. 1997). Therefore, the scatter plots of $\delta^{13} \mathrm{C}$ vs. OC/TN ratio, $\delta^{15} \mathrm{~N}$ vs. OC/TN ratio, and $\delta^{13} \mathrm{C}$ vs. $\delta^{15} \mathrm{~N}$ (Fig. 7) conceivably provide a better characterization of organic matter sources than the other scatter plots. In coastal ecosystems, plant litter, and suspended marine particles are generally considered as the main organic matter end-members. The mangrove litter contains high $\mathrm{OC}$ content (45\%), high OC/TN ratio (25-30), and depleted $\delta^{13} \mathrm{C}$ $(-28 \%)$. However, marine particulate matters are characterized by low OC $(0.5-3 \%)$, low $\mathrm{OC} / \mathrm{TN}$ ratio $(6-12)$, and variable $\delta^{13} \mathrm{C}(-28$ to $-16 \%)$. The tidal-imported marine particulate matter with high $\delta^{13} \mathrm{C}$ and low $\mathrm{OC} / \mathrm{TN}$ ratio dominates over the terrestrial/plant litter input in BS sediments (Fig. 7a). However, the plant litter is the dominant over the marine input in IS sediments, except in IS3 which is largely influenced by marine inputs (Fig. 7b). The scatter plots of $\delta^{13} \mathrm{C}$ vs. OC/TN ratio and $\delta^{13} \mathrm{C}$ vs. $\delta^{13} \mathrm{~N}$ further reinforce that marine and plant litters are the dominant $\mathrm{OM}$ inputs in $\mathrm{BS}$ and IS sediments, respectively (Fig. 7c-f).

\section{Lignin phenols}

In addition to stable isotopes, lignin phenols (phenolic acids, aldehydes, and ketones) derived after the $\mathrm{CuO}$ oxidation can also be applied to trace organic matter sources derived from vascular plants in coastal and marine ecosystems (Dittmar and Lara 2001; Prasad and Ramanathan 2009; Loh et al. 2008; Loh et al. 2012). The lignin in organic matter can be accumulated in coastal and marine sediments during diagenesis because lignin is generally highly resistant to microbial degradation in the anaerobic conditions. The $X_{\text {lignin }}$ levels of the dominant mangrove species $H$. fomes $(9.97 \%), R$. apiculata (10.77\%o), and A. marina (16.34\%o) indicate that lignin was not lost during the sedimentary diagenesis in Sundarban. Dittmar and Lara (2001) reported that lignin was removed from sediment during diagenesis in the Furo de Meio mangrove. Higher S/V ratios represent a higher abundance of angiosperms and higher $\mathrm{C} / \mathrm{V}$ ratios revealing the non-woody plant contribution (Miltner and Emeis 2001). In addition, the relatively higher ratios of $\mathrm{S} / \mathrm{V}$ and $\mathrm{C} / \mathrm{V}$ ( $>0.4$ and 0.15 , respectively) infer the dominance of non-woody angiosperm tissues drives OM dynamics in mangrove sediments (Goñi et al. 2000). The $\mathrm{S} / \mathrm{V}$ ratios in IS sediments range between 0.21 and 0.72 , and the $\mathrm{C} / \mathrm{V}$ ratio $0.32-0.35$ (Fig. 8) clearly indicates that organic matter mainly derived from the non-woody angiosperms. Similar to IS sediments, higher S/V (0.62-0.82) and $\mathrm{C} / \mathrm{V}(0.29-0.43)$ ratios characterize the predominance of non-woody angiosperm in BS sediments.

In comparison to plant litter, most of the $\mathrm{C} / \mathrm{V}$ ratios were very small, $\leq 0.4$ (Fig. 8), and indicate that the reactive entities of cinnamyl phenols, particularly $\mathrm{p}$ coumaric acid, are either released or modified during the sedimentary diagenesis. However, in BS sediments (BS1 and BS2), the C/V ratios are $>0.4$ (Fig. 8) may be due to the selective preservation of cinnamyl phenols during diagenesis. In general, cinnamyl phenols are associated with lignins by ester bonds (Kirk et al. 1980) and also with carbohydrates. The diagenetic depletion of cinnamyl phenols in coastal sediments may also be influenced by either loosely associated with the lignin molecule or bound with a chemical component which is less recalcitrant than lignin (Dittmar and Lara 2001). The PON/P ratios (IS, 0.21-0.24; BS, 0.19-0.24) are close to plant 



Fig. 7 The scatter plots of $\delta^{13} \mathrm{C}-\mathrm{OC} / \mathrm{TN}$ ratio, $\delta^{15} \mathrm{~N}-\mathrm{OC} / \mathrm{TN}$ ratio, and $\delta^{13} \mathrm{C}-\delta^{15} \mathrm{~N}$ to describe the variability in the OM dynamics in the Sundarban mangrove ecosystem

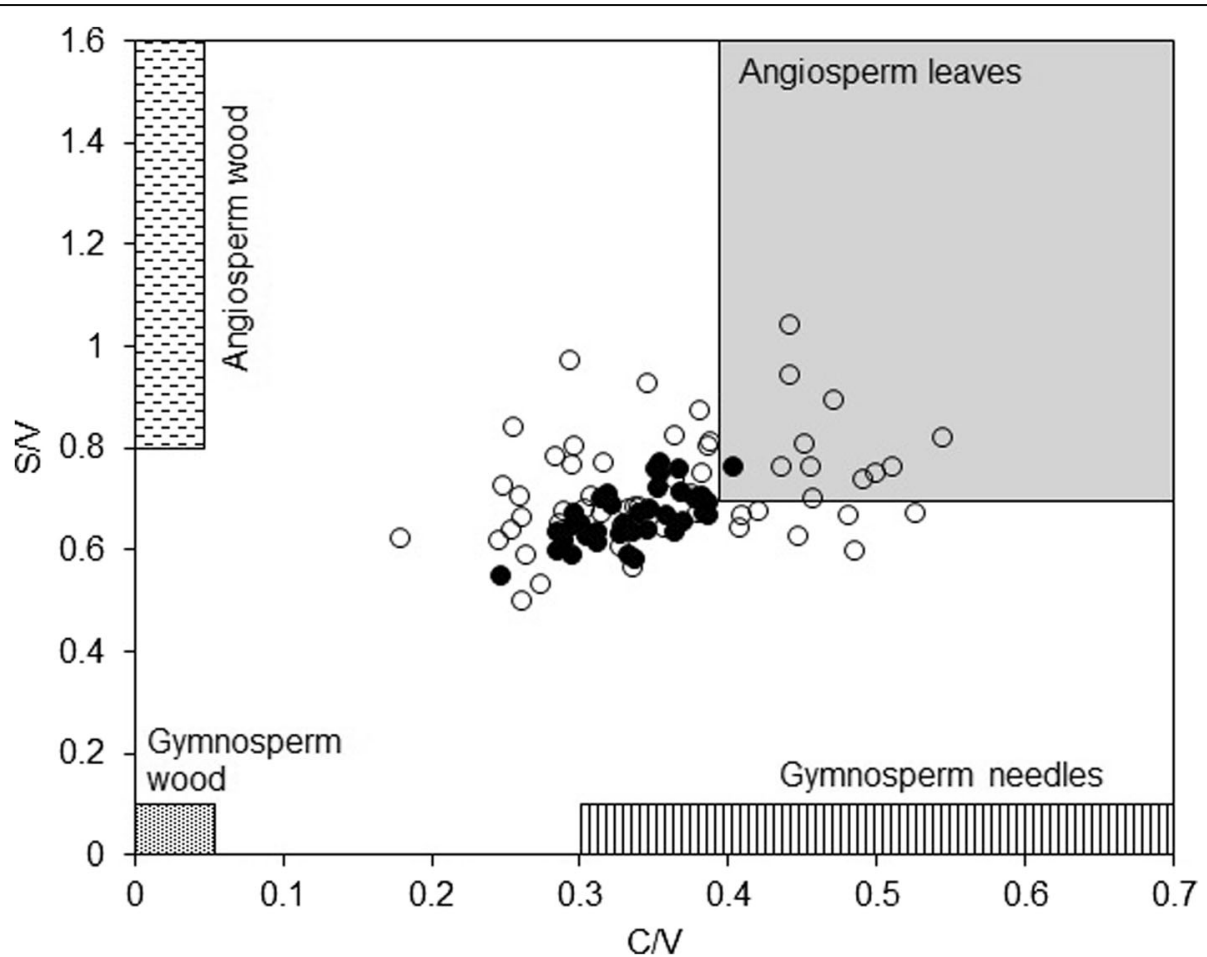

Fig. 8 Syringyl/vanillyl phenol (SN) ratio vs. cinnamyl/vanillyl phenol $(C N)$ ratio. Typical ranges for woody and non-woody tissues of both angiosperm and gymnosperm vegetation are indicated. Closed circles indicate the Indian Sundarban and open circles represent the Bangladesh Sundarban 
litter (0.19-0.24) representing the reactivity of $\mathrm{p}$ hydroxyacetophenone comparable to total p-hydroxyl phenols during diagenesis and microbial degradation (Prasad and Ramanathan 2009). In this context, $\mathrm{P} /(\mathrm{V}+\mathrm{S})$ ratio can also applied as a proxy for methylation. In aquatic ecosystems, lignin degradation generally initiated with either oxidation of propyl side chain or demethylation of the methyl groups or both. But, in both IS and BS sediments, $\mathrm{P} /(\mathrm{V}+\mathrm{S}),(\mathrm{Ad} / \mathrm{Al})_{\mathrm{V}},(\mathrm{Ad} / \mathrm{Al})_{\mathrm{S}}$, and $(\mathrm{Ad} / \mathrm{Al})_{\mathrm{P}} \mathrm{ra}-$ tios are lower than the plant litter explaining that aromatic ring cleavage may be the dominant mechanism for lignin degradation in the Sundarban sediments (Dittmar and Lara 2001; Loh et al. 2012). The Ad/Al ratios were higher than the plant litter indicating that the lignin organic matter degradation may be influenced by the oxidation of propyl side chain in the Sundarban mangrove ecosystem. Highly variable $\mathrm{S} / \mathrm{V}$ ratios were observed in both mangrove sediments which explain that the relative diagenetic activity of syringyl phenols to vanillyl phenols are largely regulated by in situ redox conditions and microbial interactions with the organic matter at the particular depth. However, the relatively constant $\mathrm{S} / \mathrm{V}$ ratio was observed in BS3 sediment suggesting a similar diagenetic activity for syringyl phenols to vanillyl phenols.

The relative contribution of terrestrial plant litter, seston, and marine POM to sedimentary organic matter has been estimated using a three end-member mixing model describing $\delta^{13} \mathrm{C}$ and $\mathrm{N} / \mathrm{C}$ ratio values of the endmembers (Goñi et al. 2003; Gonneea et al. 2004). Although slight variations in $\delta^{13} \mathrm{C}$ and $\mathrm{N} / \mathrm{C}$ ratio, terrestrial plant litter and marine POM play an important role in the biogeochemical cycling of organic matter in the both Indian and Bangladesh Sundarban mangroves (Fig. 9). In the Indian Sundarban, IS1 and IS2 samples fall inside the triangle, but few sections are around the terrestrialmarine POC transect (Fig. 9a); this indicates that both the marine inputs (core 1, 74\% and core 2, 68\%) are dominant over the terrestrial inputs (core 1, 23\% and core 2, 32\%). The top few samples from IS3 also fall along the terrestrial and marine POC transect, but these are very close to the marine-member. In case of the Bangladesh samples, except BS1 rest, are all fall well below the terrestrial-marine POC transect (Fig. 9b), this clearly indicates a combination of factors including direct inputs from marine sources and internal diagenetic processes regulate the organic matter dynamics in the Sundarban mangroves (Hicks 2007). In BS1, more than the half of the samples (mostly from the top $25 \mathrm{~cm}$ ) fall around the terrestrial and marine POC transect, this indicates that organic matter in the top $25 \mathrm{~cm}$ supplied from the combination of terrestrial and marine inputs and sedimentary diagenetic processes regulating the organic matter dynamics below $25 \mathrm{~cm}$ depth. The semidiurnal tidal activity and reduction in freshwater flow from the upstream seem to be obstructing the influence of seston in both ecosystems (Sood and Mathukumalli 2011). However, in another Indian mangrove ecosystem (Pichavaram), seston was the one of the major OM contributor (Prasad and Ramanathan 2009). This clearly depicts that the organic matter and nutrient dynamics in the intertidal mangrove ecosystems regulated by the regional hydrology, mangrove network, tidal range, diagenetic processes, and allochthonous inputs (Gonneea et al. 2004; Prasad et al. 2010).

In addition to the three end-member mixing model, the two end-member mixing ratio $\left[F_{\text {mar }}=\left\{\left(\delta^{13} C_{\text {terr }}\right.\right.\right.$ $\left.\left.-\delta^{13} C_{\text {sample }}\right) \div\left(\delta^{13} C_{\text {terr }}-\delta^{13} C_{\text {mar }}\right)\right\} \times 100$ and $F_{\text {terr }}=100$ $-F_{\text {mar }}$ ] is also employed for the quantitative estimation of relative contribution of organic matter in the Sundarban mangroves. In this estimation, we assumed $\delta^{13} \mathrm{C}$ end-member values for terrestrial origin $(-27.7 \%$ ) and marine origin $(-18 \%)$. The two end-member mixing ratio scheme also further confirms that the overwhelming amount of organic matter ( $>100 \%)$ is being supplied from marine inputs into both parts of the Sundarban mangroves. However, terrestrial inputs contribute around $10 \%$ of organic matter in IS1, IS2, IS3, and BS1 samples.

\section{Conclusions}

The fate and origin of organic matter in the Sundarban mangroves are investigated using the elemental ratios and stable isotopes of carbon $\left(\delta^{13} \mathrm{C}\right)$ and nitrogen $\left(\delta^{15} \mathrm{~N}\right)$. The regional variability in land use regulates the spatial variability in $\mathrm{C}, \mathrm{N}, \mathrm{OC} / \mathrm{TN}$ ratio, $\delta^{13} \mathrm{C}$, and $\delta^{15} \mathrm{~N}$ between the Indian and the Bangladesh Sundarban mangroves and indicates that in the upstream terrestrial, organic matter and/or mangrove plant litter contribute significant amount of organic matter, whereas the marine POC influences the organic matter dynamics in downstream. In addition, the longitudinal decline in $\delta^{13} \mathrm{C}$ levels in the Indian Sundarban and enrichment in the Bangladesh Sundarban indicates that the carbon biogeochemistry is largely regulated by a combination of factors, viz., plant litter production, total mixing with enriched organic matter, and considerable change in isotope composition due to diagenetic processes in highly redox mangrove sediments. The elevated $\delta^{15} \mathrm{~N}$ levels clearly demonstrate that anthropogenic nitrogen sources from the catchment influence the nitrogen biogeochemistry in both the Indian and the Bangladesh Sundarban mangrove. The lignin phenol monomers demonstrate that the Sundarban sediments did not lost high levels of total lignin $\left(X_{\text {lignin }}\right)$ during diagenesis. The $\mathrm{S} / \mathrm{V}$ ratio (IS: 0.21-0.72; BS: 0.62-0.82) and C/V ratio (IS: 0.32-0.35; BS: $0.29-0.43)$ indicates that organic matter predominantly derived from the non-woody angiosperms. Largely, 

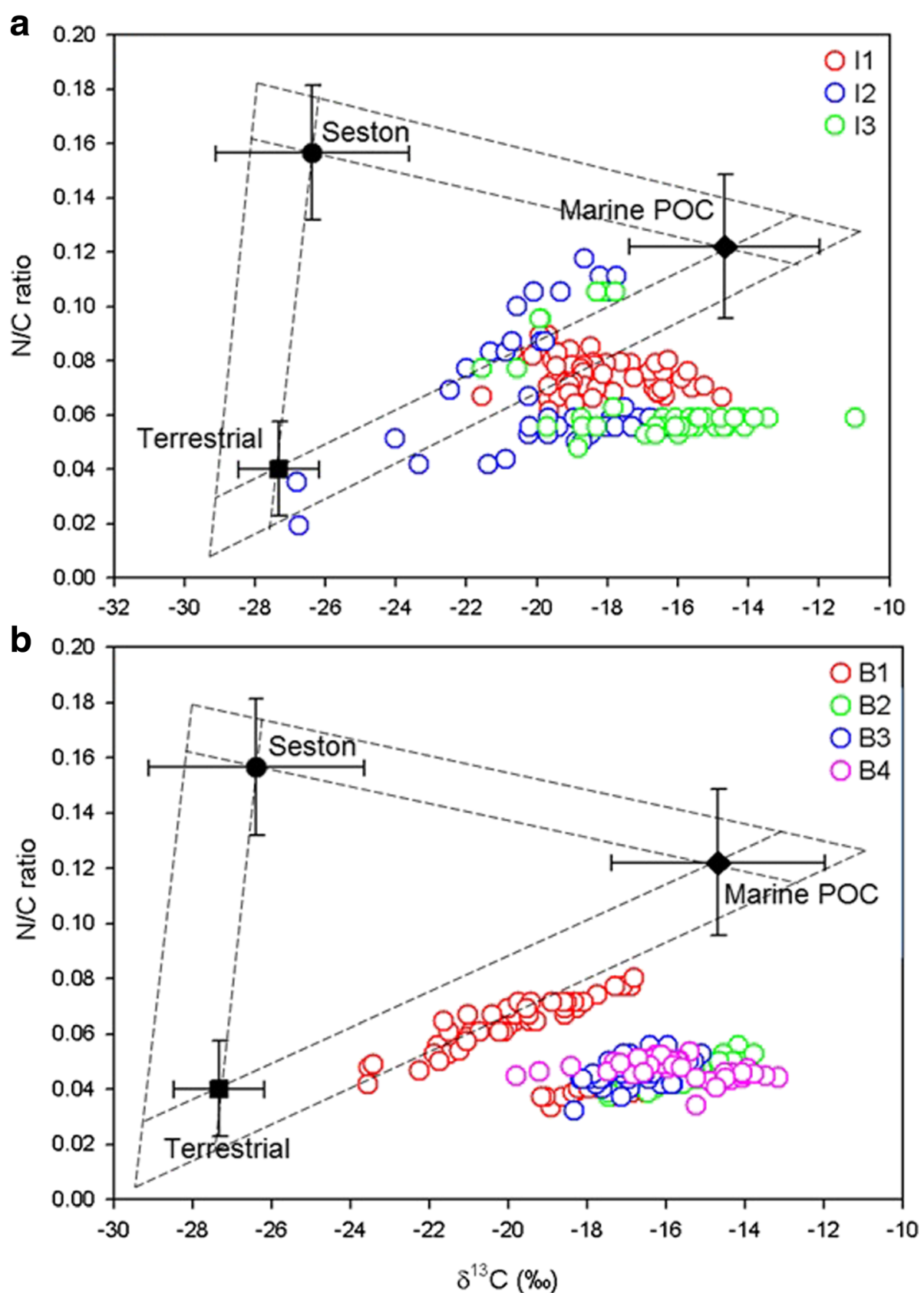

Fig. 9 The three end-member mixing plot to describe the potential contributors of OM in the Sundarban mangrove ecosystem

the $\mathrm{Ad} / \mathrm{Al}$ ratios describe that the degradation of vascular organic matter is mainly mediated by the oxidation of propyl side chain. The three end-member mixing model also further reinforces that the marine POC inputs are dominating over the terrestrial inputs in both parts of Sundarban. However, further research is required to estimate the sediment accretion rates that could facilitate to describe and estimate the carbon burial in the changing climate, which is highly required in constructing the regional carbon budgets.
Acknowledgements

This research was funded by the Asia-Pacific Network for Global Change Research, Japan. We thank Dr. Mahmood Hossain, Mr. Mohammad Raqibul Hasan Siddique, and Mr. Kushal Roy from Khulna University for their assistance in the sample collection and field analysis.

\section{Authors' contributions}

MBKP, ALR, and DKD developed the research concept and designed the project objectives. MBKP, AK, and DKD collected and prepared the samples from the field. MBKP and AK analyzed the samples. MBKP drafted the manuscript. All authors read, contributed, and approved the final manuscript. 


\section{Competing interests}

The authors declare that they have no competing interests.

\section{Author details}

${ }^{1} 22616$ Shining Harness Street, Clarksburg, MD 20871, USA. ${ }^{2}$ School of Environmental Sciences, Jawaharlal Nehru University, New Delhi 110067, India. ${ }^{3}$ Environmental Science Discipline, Khulna University, Khulna 9208 Bangladesh.

Received: 5 January 2017 Accepted: 8 February 2017

Published online: 02 March 2017

\section{References}

Andrews JE, Greenaway AM, Dennis PF (1998) Combined carbon isotope and C/Nratios as indicators of source and fate of organicmatter in a poorly flushed, tropical estuary: Hunts Bay, Kingston Harbour, Jamaica. Estuar Coast Shelf Sci 46:743-756

Baneerjee K, Chowdhury MR, Sengupta K, Mitra A (2012) Influence of anthropogenic and natural factors on the mangrove soil of Indian Sundarbans wetland. Arch Environ Sci 6:80-91

Banerjee K, Senthilkumar B, Purvaja R, Ramesh R (2012) Sedimentation and trace metal distribution in selected locations of Sundarbans mangroves and Hooghly estuary, northeast coast of India. Environ Geochem Health 34(1):27-42

Biswas H, Mukhopadhyay SK, De TK, Sen S, Jana TK (2004) Biogenic controls on the air-water carbon dioxide exchange in the Sundarban mangrove environment, northeast coast of Bay of Bengal, India. Limnol Oceanogr 49(1):95-101

Bose S (2006) Mangrove forests in Sunderbans active delta - ecolog-ical disaster and remedies. http://archive.riversymposium.com/2005/index.php?element=12.

Bouillon S, Dahdouh-Guebas F, Rao AWS, Koedam N, Dehairs F (2003) Sources of organic carbon in mangrove sediments: variability and possible ecological implications. Hydrobiologia 495:33-39

Deines P (1980) The isotopic composition of reduced organic carbon. In: Fritz P, Fontes JC (eds) Handbook of Environmental Isotope Geochemistry, vol 1, The Terrestrial Environment. A. Elsevier, Amsterdam, pp 329-406

Dittmar T, Lara RJ (2001) Driving forces behind nutrient and organic matter dynamics in a mangrove tidal creek in North Brazil. Estuar Coast Shelf Sci 52:249-259

Dittmar T, Lara RJ, Kattner G (2001) River or mangrove? Tracing major organic matter sources in tropical Brazilian coastal waters. Mar Chem 73:253-271

Dittmar T, Hertkorn N, Kattner G, Lara RJ (2006) Mangroves, a major source of dissolved organic carbon to the oceans. Global Biogeochem Cyc 20:GBS1012

Erwin KL (2009) Wetlands and global climate change: the role of wetland restoration in a changing world. Wetland Ecol Mgmt 17(1):71-84

Goñi MA, Yunker MB, Macdonald RW, Eglinton TI (2000) The supply and preservation of organic biomarkers in arctic sediments from the Mackenzie River and Beaufort Shelf. Mar Chem 71:23-51

Goñi M, Teixeira M, Perkey D (2003) Sources and distribution of organic matter in a river-dominated estuary (Winyah Bay, SC, USA). Estuar Coast Shelf Sci 57:1023-1048

Gonneea ME, Paytan A, Herrera-Silveira JE (2004) Tracing organic matter sources and carbon burial in mangrove sediments over the past 160 years. Estuar Coast Shelf Sci 61:211-227

Gopal B, Chauhan M (2006) Biodiversity and its conservation in the Sundarban mangrove ecosystem. Aquat Sci 68:338-354

Groffman PM, Bohlen PJ (1999) Soil and sediment biodiversity: cross-system comparisons and large-scale effects. Bioscience 49(2):139-148

He B, Dai M, Huang W, Liu Q, Chen H, Xu L (2010) Sources and accumulation of organic carbon in the Pearl River Estuary surface sediment as indicated by elemental, stable carbon isotopic, and carbohydrate compositions. Biogeosciences 7:3343-3362

Hedges Jl, Ertel JR (1982) Characterization of lignin by gas capillary chromatography of cupric oxide oxidation products. Anal Chem 54:174-178

Hedges Jl, Keil RG, Benner R (1997) What happens to terrestrial organic matter in the ocean? Org Geochem 27:195-212

Hicks C (2007) Sediment organic carbon pools and sources in a recently constructed mangrove and seagrass ecosystem. MS dissertation, University of Florida.

Jennerjahn TC (2012) Biogeochemical response of tropical coastal systems to present and past environmental change. Earth Sci Rev 114:19-41

Kirk TK, Higuchi T, Chang HM (1980) Lignin biodegradation: microbiology, chemistry and potential applications. CRC Press Inc., Boca Raton

Kristensen E, Bouillon S, Dittmar T, Marchand C (2008) Organic matter dynamics in mangrove ecosystems. Aquat Bot 89:201-219
Lamb AL, Wilson GP, Leng MJ (2006) A review of coastal palaeoclimate and relative sea-level reconstructions using $\delta^{13} \mathrm{C}$ and $\mathrm{C} / \mathrm{N}$ ratios in organic material. Earth-Sci Rev 75:29-57

Lobbes JM, Fitznar HP, Kattner G (1999) High-performance liquid chromatography of lignin-derived phenols in environmental samples with diode detection. Anal Chem 71:3008-3012

Loh PS, Reeves AD, Harvey SM, Overnell J, Miller AEJ (2008) The fate of terrestrial organic matter in two Scottish sea lochs. Estuar Coast Shelf Sci 76:566-579

Loh PS, Chen C-T, Anshari GZ, Wang JT, Lou JY, Wang SL (2012) A comprehensive survey of lignin geochemistry in the sedimentary organic matter along the Kapuas River (West Kalimantan, Indonesia). J Asian Earth Sci 43:118-129

Mandal RN, Das CS, Naskar KR (2012) Dwindling Indian Sundarban mangrove: the way out. Sci Cul 76(7-8):275-282

Meyers PA, Arnaboldi M (2008) Paleoceanographic implications of nitrogen and organic carbon isotopic excursions in mid-Pleistocene sapropels from the Tyrrhenian and Levantine Basins, Mediterranean Sea. Palaeogeogr Palaeoclimatol Palaeoecol 266:112-118

Miltner A, Emeis KC (2001) Terrestrial organic matter in surface sediments of the Baltic Sea, NW Europe, as determined by CuO oxidation. Geochim Cosmochim Acta 65(8):1285-1299

Mitra A, Gangopadhyay A, Dube A, Schmidt ACK, Banerjee K (2009) Observed changes in water mass properties in the Indian Sundarbans (northwestern Bay of Bengal) during 1980-2007. Cur Sci 97(10):1445-1452

Muzuka ANN, Shunula JP (2006) Stable isotope compositions of organic carbon and nitrogen of two mangrove stands along the Tanzanian coastal zone. Estuar Coast Shelf Sci 66:447-458

Prahl FG, De Lange GT, Scholten S, Cowie GL (1997) A case of post-depositional aerobic degradation of terrestrial organic matter in turbidite deposits from the Madeira Abyssal Plain. Org Geochem 27:141-152

Prasad MBK, Ramanathan AL (2008) Sedimentary nutrient dynamics in a tropical estuarine mangrove ecosystem. Estuar Coast Shelf Sci 80:60-66

Prasad MBK, Ramanathan AL (2009) Organic matter characterization in a tropical estuarine-mangrove ecosystem of India: preliminary assessment by using stable isotopes and lignin phenols. Estuar Coast Shelf Sci 84(4):617-624

Prasad MBK, Dittmar T, Ramanathan AL (2010) Organic matter and mangrove productivity. In: Ramanathan AL, Bhattacharya P, Dittmar T, Prasad MBK, Nepaune B (eds) Management and Sustainable Development of the Coastal Zone Environments. Springer, New Delhi, pp 175-193

Prasad MBK, Kaushal SS, Murtugudde R (2013) Long-term pCO2 dynamics in rivers in the Chesapeake Bay watershed. Appl Geochem 31:209-215

Preston T, Owens NJP (1983) Interfacing an automatic elemental analyser with an isotope ratio mass spectrometer: the potential for fully automated total nitrogen and nitrogen-15 analysis. Analyst 108:971-977

Ranjan RK, Routh J, Ramanathan AL, Val Klump J (2011) Elemental and stable isotope records of organic matter input and its fate in the Pichavaram mangrove-estuarine sediments (Tamil Nadu, India). Mar Chem 126:163-172

Rundegren N, Loader NJ, Hammarlund D (2003) Stable carbon isotope composition of terrestrial leaves: inter- and intraspecies variability, cellulose and whole-leaf tissue difference and potential for climate reconstruction. J Quat Sci 18:583-590

Singh A, Ramesh R (2011) Contribution of riverine dissolved inorganic nitrogen flux to new production in the coastal northern Indian Ocean: an assessment. Int J Oceanogr. doi:10.1155/2011/983561

Sood A, Mathukumalli MBK (2011) Managing international river basins: reviewing India-Bangladesh transboundary water issues. Int J River Basin Mgmt 9(1):43-52

Sweeney RE, Kaplan IR (1980) Natural abundances of ${ }^{15} \mathrm{~N}$ as a source indicator for near-shore marine sedimentary and dissolved nitrogen. Mar Chem 9:81-94

Thimdee W, Deein G, Sangrungruang C, Nishioka J, Matsunaga K (2003) Sources and fate of organic matter in Khung Krabaen Bay (Thailand) as traced by $\delta^{13} \mathrm{C}$ and $\mathrm{C} / \mathrm{N}$ atomic ratios. Wetlands 23(4):729-738

Thornton SF, McManus J (1994) Application of organic carbon and nitrogen stable isotopes and $\mathrm{C} / \mathrm{N}$ ratios as source indicators of organic matter provenance in estuarine systems: evidence from the Tay Estuary, Scotland. Estuar Coast Shelf Sci 38:219-233

Tue NT, Hamaoka H, Sogabe A, Quy TD, Nhuan MT, Omori K (2011) Sources of sedimentary organic carbon in mangrove ecosystems from Ba Lat estuary, Red River, Vietnam. In: Omori K, Guo X, Yoshie N, Fujii N, Handoh IC, Isobe A, Tanabe $S$ (eds) Interdisciplinary Studies on Environmental Chemistry-Marine Environmental Modeling \& Analysis. Terrapub, pp. 151-157 
Wigand C, McKinney RA, Cole ML, Thursby GB, Cummings J (2007) Varying stable nitrogen isotope ratios of different marsh plants and their relationships with wastewater nitrogen and land use in New England, USA. Environ Monit Asses 131:71-81

Wooller MJ, Smallwood B, Jacobson M, Fogel M (2003) Carbon and nitrogen stable isotopic variation in Laguncularia racemosa from Florida and Belize: implication for trophic level studies. Hydrobiologia 499:13-23

\section{Submit your manuscript to a SpringerOpen ${ }^{\circ}$ journal and benefit from:}

- Convenient online submission

- Rigorous peer review

- Immediate publication on acceptance

- Open access: articles freely available online

- High visibility within the field

- Retaining the copyright to your article

Submit your next manuscript at $>$ springeropen.com 